\title{
46. BIOSTRATIGRAPHIC SYNTHESIS, DEEP SEA DRILLING PROJECT LEG 90 IN THE SOUTHWEST PACIFIC OCEAN 1
}

\author{
Erlend Martini, Geologisch-Paläontologisches Institut der Universität, Frankfurt am Main \\ and \\ D. Graham Jenkins, Department of Earth Sciences, Open University ${ }^{2}$
}

\begin{abstract}
During Leg 90 the sequences cored at Sites 587 to 594 , drilled in subtropical to subantarctic waters, were dated by analyses of calcareous nannoplankton and planktonic foraminifers. We summarize the general stratigraphic distribution of these and other fossil groups, including fish otoliths, mollusks, pteropods, ostracodes, echinoids, benthic foraminifers, radiolarians, diatoms, silicoflagellates, ebridians, actiniscidians, sponge spicules, and phytoliths.

Placement of the four major epoch boundaries from late Eocene to Pleistocene at the different sites was based mainly on calcareous nannoplankton and planktonic foraminifers. We discuss the various taxa used to define these boundaries and the biostratigraphic problems involved in correlating sequences in a latitudinal traverse that ranges from $21^{\circ}$ to $45^{\circ} \mathrm{S}$.

Hiatuses at Sites 588 (late Eocene/late Oligocene) and 592 (late Oligocene/early Miocene) are recorded, and the factors that may have formed these unconformities are briefly described.
\end{abstract}

\section{INTRODUCTION}

During Leg 90 of the Deep Sea Drilling Project, eight sites were occupied and 18 holes drilled in the New Caledonia and New Zealand regions (Fig. 1, Table 1). All sites have yielded abundant calcareous nannoplankton and foraminifers, whereas radiolarians, diatoms, silicoflagellates, and some other groups are restricted to certain sites and stratigraphic levels. The occurrences and general trends of each group are discussed below.

In a traverse between equatorial and northern subantarctic water masses in the southwest Pacific, highquality middle to late Cenozoic sections were obtained at all Leg 90 sites and at Site 586, drilled during Leg 89 but incorporated in the Initial Reports for Legs 89 and 90. At all sites, sediments are presently deposited well above the CCD; this is also true for the middle Eocene and younger sediments cored. Time intervals covered by the cores are shown for each site in Figure 2. However, one of the main objectives of Leg 90 was not achieved. It proved impossible to correlate the biostratigraphic events with the paleomagnetic record; generally, the original paleomagnetic signatures in the sediments were too weak to measure (Barton and Bloemendal, this volume). Thus it was not possible to demonstrate accurately the degree to which some taxa were diachronous.

\section{OCCURRENCE AND GENERAL TRENDS OF VARIOUS GROUPS}

Calcareous plankton are abundant and benthic foraminifers widespread at all sites and all levels cored. How-

\footnotetext{
${ }^{1}$ Kennett, J. P., von der Borch, C. C., et al., Init. Repts. DSDP, 90: Washington (U.S. Govt, Printing Office).

2 Addresses: (Martini) Geologisch-Paläontologisches Institut der Universităt, SenckenbergAnlage 32-34, D6000 Frankfurt am Main, Federal Republic of Germany; (Jenkins) Department of Earth Sciences, Open University, Walton Hall, Milton Keynes MK7 6AA, Buckinghamshire, England.
}

ever, siliceous plankton are restricted to certain areas and levels. Diatoms, silicoflagellates, radiolarians, ebridians, actiniscidians, and sponge spicules are present only in sediments from the middle Eocene at Site 588, the middle Miocene to early Pliocene at Site 591, and the middle Miocene to early Quaternary at the southernmost Site 594. Radiolarians also occur in lower frequencies in Miocene sediments at Site 590 and in the upper Eocene at Site 592.

Site 594 is just south of the present-day Subtropical Convergence. This site exhibits typical cold-water flora and fauna, in which siliceous groups are normally well represented, dating back to the middle Miocene. The occurrence of siliceous plankton in the middle Miocene to lower Pliocene of Site 591 and in the lower Miocene to lower Pleistocene of adjacent Site 206 (Leg 21) is important, because neither nearby Site 590 to the west nor Site 588 to the north and Site 592 to the south show similar occurrences during these intervals. At the moment, no obvious explanation can be offered for local occurrences, although upwelling may have enhanced biogenic productivity.

\section{Fish Otoliths}

Fish otoliths, predominantly belonging to the Lanternfishes (Myctophidae), were found in the Quaternary of Sites 587 and 594. Most of the otoliths are badly worn, but some are fairly well preserved and could be identified generically and in some cases specifically (Martini and Gaemers, this volume).

\section{Mollusks}

Mollusk fragments were noted in Core 592-34, of early Oligocene age. The better-preserved specimens were tentatively identified as Ostrea sp. A few juvenile Chlamys were found in the late Quaternary at Site 594. 


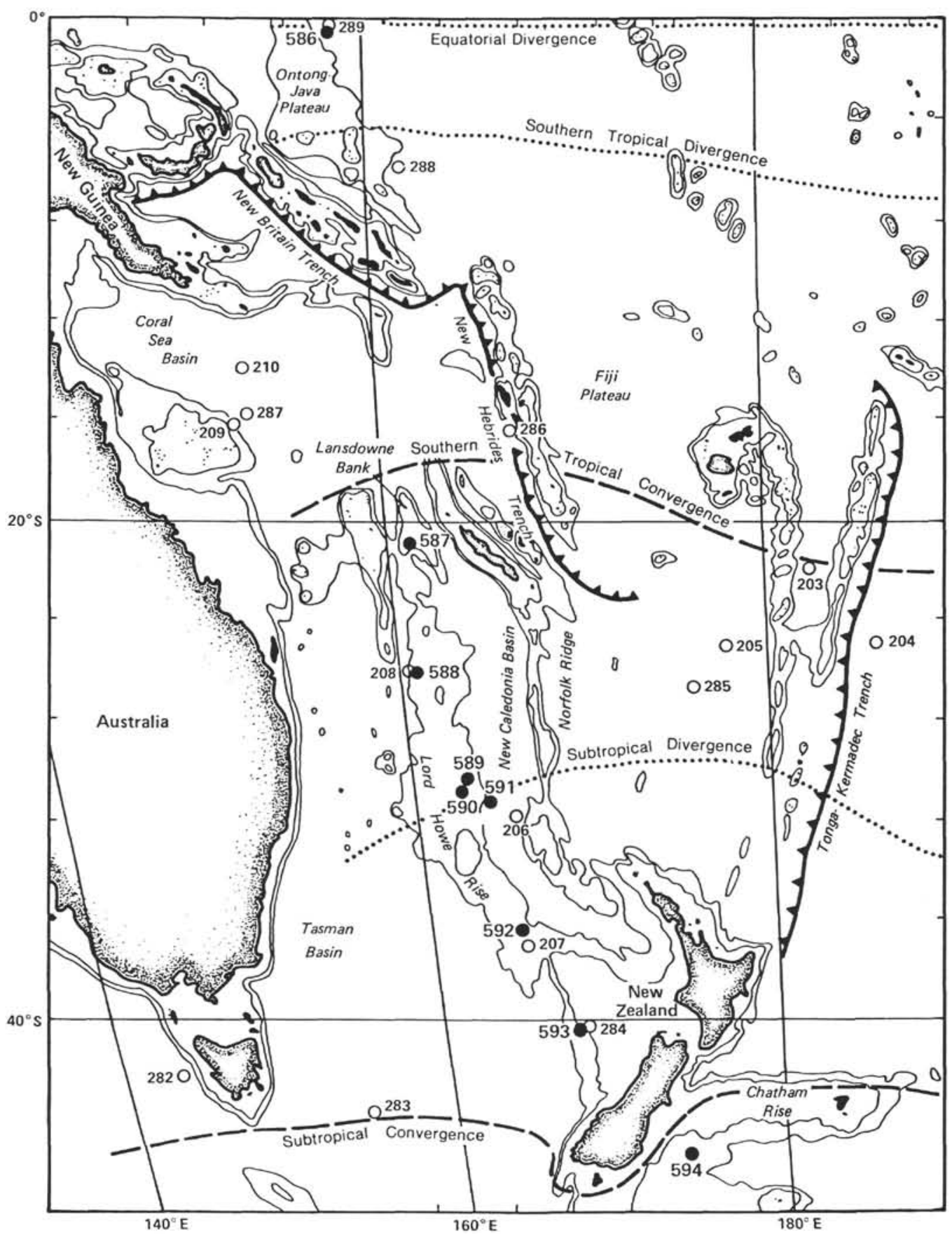

Figure 1. Location of sites drilled during Leg 90 (solid circles) and other DSDP drill sites (open circles) in the southwest Pacific.

\section{Pteropods, Ostracodes, and Echinoids}

Representatives of these groups were noted in Quaternary samples from several holes but were not investigated in detail. Pteropods are especially common in the uppermost samples of Site 587. They include the circumtropical species Diacria quadridentata, and Creseis cf. virgula as well as the Indo-Pacific species Atlanta turriculata. Pteropods were not found at the southernmost Site 594, where ostracodes and echinoid spines form a varying but constant constituent in the Quaternary samples.

\section{Planktonic Foraminifers}

In general, samples from Site 586 in the tropical province to Site 594 in subantarctic waters yielded excellent planktonic foraminiferal faunas. Because of the changes in the faunas from the equatorial region to Site 594 at latitude $45^{\circ} \mathrm{S}$, five zonal schemes were used, and intersite correlation was established by using selected datum species. Most of the extinctions and initial appearances of datum species appear to be relatively isochronous, except at the paleogeographic limits of some species, where a few were demonstrably diachronous, including the ap- 
Table 1. Locations and water depths of Leg 90 sites.

\begin{tabular}{lclc}
\hline & $\begin{array}{c}\text { Latitude } \\
(\mathrm{S})\end{array}$ & $\begin{array}{c}\text { Longitude } \\
(\mathrm{E})\end{array}$ & $\begin{array}{c}\text { Water } \\
\text { depth } \\
(\mathrm{m})\end{array}$ \\
\hline 586 & $00^{\circ} 29.84^{\prime}$ & $158^{\circ} 29.89^{\prime}$ & 2207 \\
587 & $21^{\circ} 11.87^{\prime}$ & $161^{\circ} 19.99^{\prime}$ & 1101 \\
588 & $26^{\circ} 06.7^{\prime}$ & $161^{\circ} 13.6^{\prime}$ & 1533 \\
589 & $30^{\circ} 42.72^{\prime}$ & $163^{\circ} 38.39^{\prime}$ & 1391 \\
590 & $31^{\circ} 10.02^{\prime}$ & $163^{\circ} 21.51^{\prime}$ & 1299 \\
591 & $31^{\circ} 35.06^{\prime}$ & $164^{\circ} 26.92^{\prime}$ & 2131 \\
592 & $36^{\circ} 28.40^{\prime}$ & $165^{\circ} 26.53^{\prime}$ & 1098 \\
593 & $40^{\circ} 30.47^{\prime}$ & $167^{\circ} 40.47^{\prime}$ & 1068 \\
594 & $45^{\circ} 31.41^{\prime}$ & $174^{\circ} 56.88^{\prime}$ & 1204 \\
\hline
\end{tabular}

pearances of Globorotalia truncatulinoides at Site 594 and G. inflata at Site 587 (Jenkins and Srinivasan, this volume).

Stratigraphic range charts of Sites 586 to 594 are provided, selected taxonomic problems are discussed, and
39 species are illustrated in Jenkins and Srinivasan (this volume). Some details of the last or first occurrences of important species around the major boundaries from the Eocene onward are also discussed below and are illustrated in Figures 3 to 8.

\section{Benthic Foraminifers}

Benthic foraminifers are present at all sites and cored intervals. Redeposited shallow-water foraminifers were noted at Site 587. Assemblages and regional differences along the traverse from Site 586 to the southernmost Site 594 are described in detail by Boersma (this volume).

\section{Calcareous Nannoplankton}

Calcareous nannoplankton are present in all holes and are described in detail for the Neogene and Quaternary by Lohman (this volume) and for the Paleogene by Martini (this volume). The standard nannoplankton zonation (Martini, 1971) is used at all sites to identify nanno-

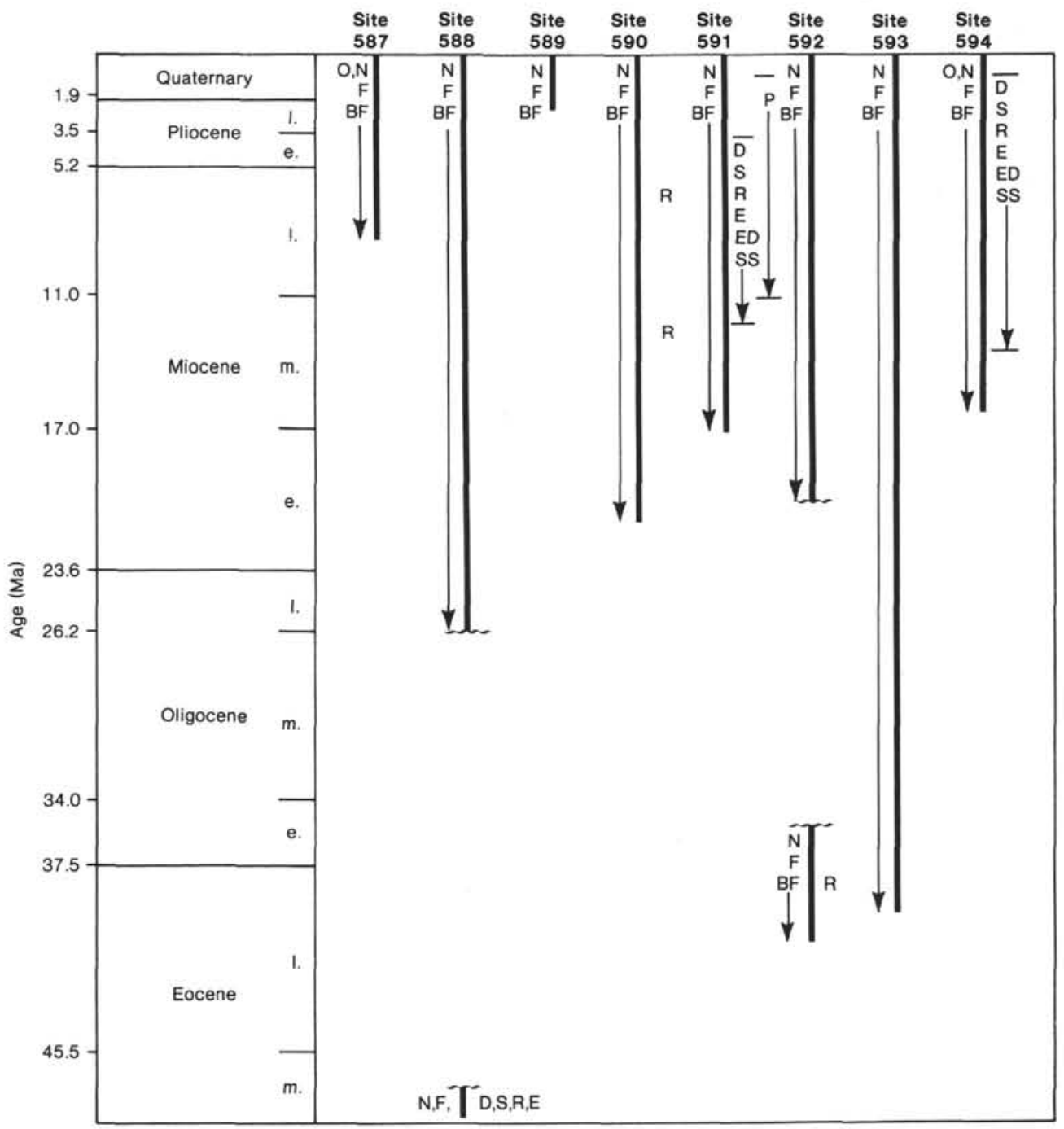

Figure 2. Intervals recovered during Leg 90 in the southwest Pacific, and occurrence of various fossil groups. $\mathrm{O}=$ fish otoliths, $\mathrm{N}=$ calcareous nannoplankton, $\mathrm{F}=$ planktonic foraminifers, $\mathrm{BF}=$ benthic foraminifers, $\mathrm{D}=$ diatoms, $\mathrm{S}=$ silicoflagellates, $\mathrm{R}=$ radiolarians, $\mathrm{E}=$ ebridians, $\mathrm{ED}=$ endoskeletal dinoflagellates, $\mathrm{SS}=$ sponge spicules, $\mathrm{P}=$ phytoliths. Mollusks, pteropods, ostracodes, and echinoids omitted. 
plankton zones. However, from Site $592\left(36^{\circ} 28.40^{\prime} \mathrm{S}\right)$ southward, zones based on Discoaster, Ceratolithus, Catinaster, and Sphenolithus species had in some cases to be combined, because most of these species do not occur in subantarctic waters. In the middle and late Oligocene of Site 593, sphenoliths and Helicosphaera recta are either rare or missing, and substitute species such as Blackites tenuis and Zygrhablithus bijugatus were used. In the Miocene and especially in the Pliocene at Site $594\left(45^{\circ} 31.41^{\prime} \mathrm{S}\right)$ and, to a lesser extent, at Site 593 $\left(40^{\circ} 30.47^{\prime} \mathrm{S}\right)$, discoasters are missing or occur only as rare specimens, not reliable for zonation. Thus large intervals had to be combined, as in the nannoplankton zonation used in the northern high latitudes of the Atlantic and the Norwegian-Greenland Sea (Leg 38, Müller, 1976; Leg 49, Martini, 1979). This poses a particular problem for the identification of the Pliocene/Pleistocene boundary, which elsewhere is commonly placed at the last occurrence of discoasters (see later discussion).

In the Quaternary, calcareous nannoplankton are generally well preserved at all sites. However, as depth increases preservation changes from good to moderate in the Pliocene and deteriorates to poor in some of the early Miocene assemblages. Preservation in the Paleogene at Sites 588, 592, and 593 varies between poor and moderate. In Hole 588C, discoasters, especially in the Oligocene, are overgrown, as are some of the Oligocene Discolithina specimens.

\section{Radiolarians}

Radiolarians were noted during routine shipboard work in the middle Eocene section of Hole $588 \mathrm{C}$ and below Sample 590B-25,CC (middle upper Miocene) at Site 590, but do not occur in sufficient numbers for detailed investigations. Fragments of radiolarians were found in smear slides from various levels at Site 591, indicating that this group was present throughout most of the section cored; in Sample 591B-5,CC (upper Miocene), for example, radiolarians are rather common but were not investigated in detail. At Site 592, radiolarians are present only in part of the upper Eocene and are not very different from the tropical faunas. Hence the classic biostratigraphy of Riedel and Sanfilippo (1971) has been used. At Site 594, radiolarians are rare throughout the cores because of the great dilution by terrigenous material. Equatorial and high-latitude assemblages were mixed and, accordingly, zonations proposed for both regions have been employed (Caulet, this volume). Subantarctic or antarctic species are recognized only in Plio/Pleistocene samples, whereas radiolarian faunas below Section 594-23-1 are composed of temperate species. This change occurs near the Miocene/Pliocene boundary.

\section{Diatoms}

Diatoms are present in the middle Eocene of Hole $588 \mathrm{C}$ and are especially common in Core $588 \mathrm{C}-19$, where representatives of Triceratium, Actinoptychus, Trochosira, and Thalassiosira are included in the well-diversified assemblage. At Site 591, diatoms occur in fair numbers throughout most of the section, but the occurrences are heavily masked by vast numbers of foraminifers and calcareous nannoplankton. Diatoms are present also in most Site 594 samples from the middle Miocene up to the Quaternary (Ciesielski, this volume). Reworked Eocene and Oligocene diatoms are common throughout the sequence.

\section{Silicoflagellates}

Silicoflagellates are rather frequent in the middle Eocene from Site 588, in the middle Miocene to lower Pliocene from Site 591, and in the middle Miocene to Quaternary at Site 594. At Sites 591 and 594 a detailed silicoflagellate zonation is possible, although because of the latitudinal change some differences are obvious in the silicoflagellate assemblages at the sites. Comparison between the sequences recovered at Sites 591 and 206 (Leg 21) revealed two hiatuses in the latter, but helped to establish a zonation for this area from the early Miocene to the Pleistocene and a correlation to standard nannoplankton zones. Two new genera, two new subspecies, and three new forms are described from this material (Locker and Martini, this volume). Reworked Eocene and Oligocene silicoflagellates were noted in most of the Neogene and Quaternary samples of Site 594.

\section{Ebridians and Actiniscidians}

Ebridians and actiniscidians (so-called endoskeletal dinoflagellates) were found at three sites. Hole 588C yielded middle Eocene ebridians. At Site 591, ebridians and actiniscidians are rather common in the middle Miocene and lower Pliocene and are investigated in detail (Locker and Martini, this volume). In Holes 594 and 594A both groups were noted sporadically in the middle Miocene to Pleistocene, including reworked forms from the Paleogene. The middle Miocene to lower Pliocene at Site 591 can be subdivided into five ebridian-actiniscidian zones. Five new species are described from this material.

\section{Sponge Spicules}

Sponge spicules were noted in the middle Eocene of Hole 588C and at Sites 591 and 594, where they are associated with diatoms, silicoflagellates, and ebridians. A few specimens are figured by Locker and Martini (this volume).

\section{Phytoliths}

Phytoliths were found in fair numbers in Holes 591, 591A, and 591B, and very sporadically also in Hole 594A, but were investigated only in the first three holes (Locker and Martini, this volume). They are derived from the semiarid regions of Australia, whence they were blown by westerly winds into the Tasman Sea area. The stratigraphic record ranges from the middle Miocene $(\sim 14$ $\mathrm{Ma})$ to the early Pleistocene.

\section{MAJOR BOUNDARIES}

All major boundaries from the Eocene onward were encountered at Leg 90 and are discussed with respect to planktonic foraminifers and calcareous nannoplankton.

\section{Eocene/Oligocene Boundary}

The Eocene/Oligocene boundary as identified by calcareous nannoplankton is commonly placed at the last occurrence of the rosette-shaped discoasters which dom- 
inate in the Eocene, especially the last occurrence of Discoaster saipanensis (top of Zone NP20; Martini, 1971) in deep-sea sediments and land-based sections of low and middle latitudes. Several authors that have discussed the dating of the Eocene/Oligocene boundary by calcareous nannoplankton and foraminifers (e.g., Bombita and Rusu, 1981; Snyder et al., 1984) have shown that the boundary determined using planktonic foraminifers (commonly the last occurrence of Globorotalia cerroazulensis) is slightly younger than that determined using calcareous nannoplankton and occurs in the lower part of nannoplankton Zone NP21. The time-span between the two boundary "events" is about $0.4 \mathrm{~m}$.y. as determined from the sedimentation rate at Site 592 (Martini, this volume). In high latitudes, discoasters are generally rare or are missing and thus not so reliable for indicating the position of the Eocene/Oligocene boundary. However, Cribrocentrum reticulatum last occurs just below the Eocene/Oligocene boundary (top of Zone NP20, last occurrence of $D$. saipanensis) in low and middle latitudes and can also be used as a reliable substitute species at high latitudes (Müller, 1978).

At Sites 592 and 593 the extinction of Globigerinatheka index was used to mark the boundary, following the work of Finlay (1939), Hornibrook (1958), and Jenkins $(1963,1966)$ in New Zealand. Other taxa such as Hantkenina and Globorotalia cerroazulensis s.l. became extinct below the boundary in the late Eocene in the mid to high latitudes of the southwest Pacific. At Site 592 the last occurrences of $D$. saipanensis and $D$. barbadiensis were used to define the nannoplankton-based Eocene/Oligocene boundary at Sample 592-37-2, 33-34 $\mathrm{cm}$ (Fig. 3). In contrast, at Site 593, the last rare occurrences of these species are in Core 60, below the last occurrence of $C$. reticulatum in Sample 593-59,CC (see Fig. 4). Thus the disappearances of these two Discoaster species are slightly diachronous at these latitudes with respect to the extinction of $C$. reticulatum and not reliable at this site.

It has been fairly well established that there was a significant lowering of oceanic temperature in the earliest Oligocene, coinciding with paleomagnetic Anomaly 13 at Site 522 in the South Atlantic (Poore and Matthews, 1983), after the extinctions of Globigerinatheka index, Hantkenina, and Globorotalia cerroazulensis. This drop in temperature is detected at Site 592 in Core 35, after the extinction of $G$. index is noted in Sample 592-36-3, 90-91 cm (Murphy and Kennett, this volume). At Site 593 , the same set of extinctions occurs, that is, $D$. barbadiensis and $D$. saipanensis followed by $G$. index.

\section{Oligocene/Miocene Boundary}

At Sites 586, 588, and 593 the Oligocene/Miocene boundary was encountered. Details on last and first occurrences of calcareous nannoplankton and planktonic foraminifers near the boundary are presented in Figures 5 and 6.

At Sites 586, 588, and 593 the initial appearance of Globoquadrina dehiscens was used to mark the boundary; this follows the work of Jenkins $(1966,1971)$ and Srinivasan and Kennett (1983). Jenkins $(1971,1981)$ has suggested that $G$. dehiscens evolved and appeared earlier in the middle latitudes, compared with its cryptogenic appearance at low latitudes.

The Oligocene/Miocene boundary as defined by calcareous nannoplankton is generally placed at the top of nannoplankton Zone NP25 (Steininger, 1982), where several nannoplankton species, such as Sphenolithus ciperoensis, Helicosphaera recta, and Zygrhablithus bijugatus, have their last occurrences. Dictyococcites dictyodus, which may be used in certain areas as an additional boundary indicator, is not very reliable because of its varying last occurrence. For example, in the central Pacific it last occurs at the top of Zone NP23 (DSDP Site 317), whereas in the southwest Pacific the last occurrence is well within Zone NN1 (DSDP Site 593). Some workers, such as Okada (1980), identify the Cyclicargolithus abisectus Acme Zone of Bukry (1973) as the last zone within the Oligocene. Although C. abisectus ranges up to the lower part of Zone NN6 (Discoaster exilis Zone), it has several acmes up to this level and cannot be used to define a useful zone near the Oligocene/Miocene boundary.

At Site 593 , the boundary was identified by the last occurrence of $H$. recta and $Z$. bijugatus and is very close to the boundary as defined by the first appearance of Globoquadrina dehiscens. However, in Hole 588C, the boundary identified by calcareous nannoplankton has a considerable offset compared with that identified by planktonic foraminifers (Fig. 5). Detailed nannoplankton studies from Cores 4 to 9 reveal a consistent presence of $H$. recta up to Sample 588C-6-2, 0-1 cm, but rather scattered occurrences of Z. bijugatus and Discolithina enormis in Cores 6 to 9. The last common occurrence of Z. bijugatus (Sample 588C-10-2, $24 \mathrm{~cm}$ and the first occurrence of Sphenolithus capricornutus (Sample $588 \mathrm{C}-9, \mathrm{CC})$ were noted close to the first appearance of G. dehiscens in Sample 588C-9-3, 40-41 cm, in a similar position to that found in Hole 593 (Fig. 6).

\section{Miocene/Pliocene Boundary}

The placement of this boundary using planktonic foraminifers presented some problems on Leg 90. At the tropical/subtropical Sites 586 and 587 the first appearance of Globorotalia tumida was used, but it became progressively rarer in the southward traverse and at the other Sites 588 and 590 and 594 the boundary was placed by the extinction of $G$. conomiozea, a species which commonly occurs also in New Zealand sections of late Miocene age (Hornibrook, 1984).

Without reliable paleomagnetic data it is difficult to prove, but Jenkins and Srinivasan (this volume) believe that this extinction was probably diachronous. Data for some important calcareous nannoplankton species around the Miocene/Pliocene boundary seem to support this assumption (Fig. 7). The first appearance of $G$. tumida seems to be an unreliable marker, since its datum line crosses the datum lines of Ceratholithus rugosus (FAD) and Discoaster quinqueramus (LAD) between Sites 587 and 588 . Both are crossed back again by the $G$. conomiozea datum (LAD) between Sites 588 and 591. At Site 594 the extinction level of $G$. conomiozea was noted even 


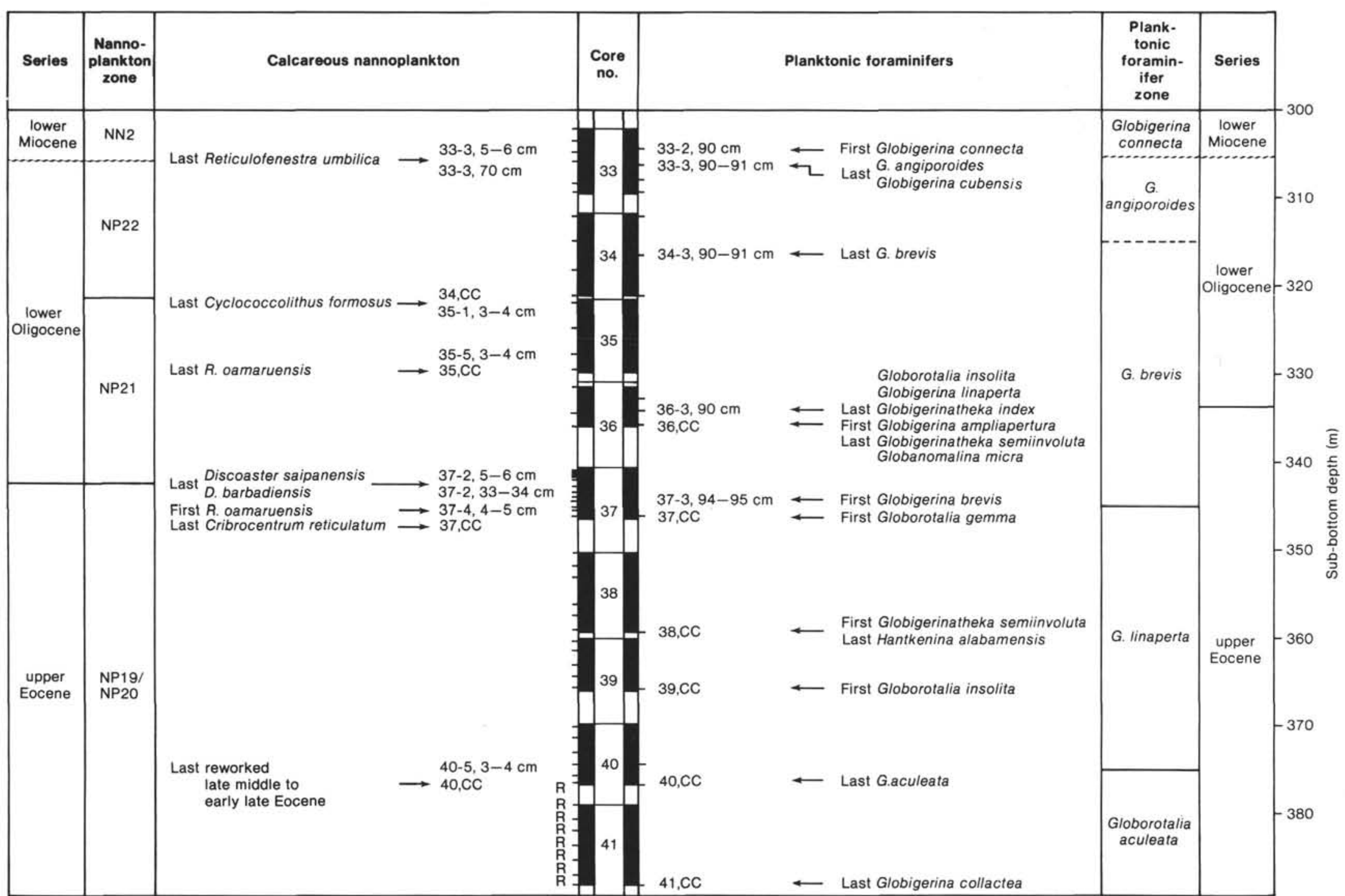

Figure 3. Last or first occurrences of important calcareous nannoplankton and planktonic foraminiferal species about the Eocene/Oligocene boundary in $\mathrm{Hole} 592$, at $36^{\circ} 28.40^{\prime} \mathrm{S}$. Black = recovered material, $\mathrm{R}=$ reworked middle to early late Eocene calcareous nannoplankton. 


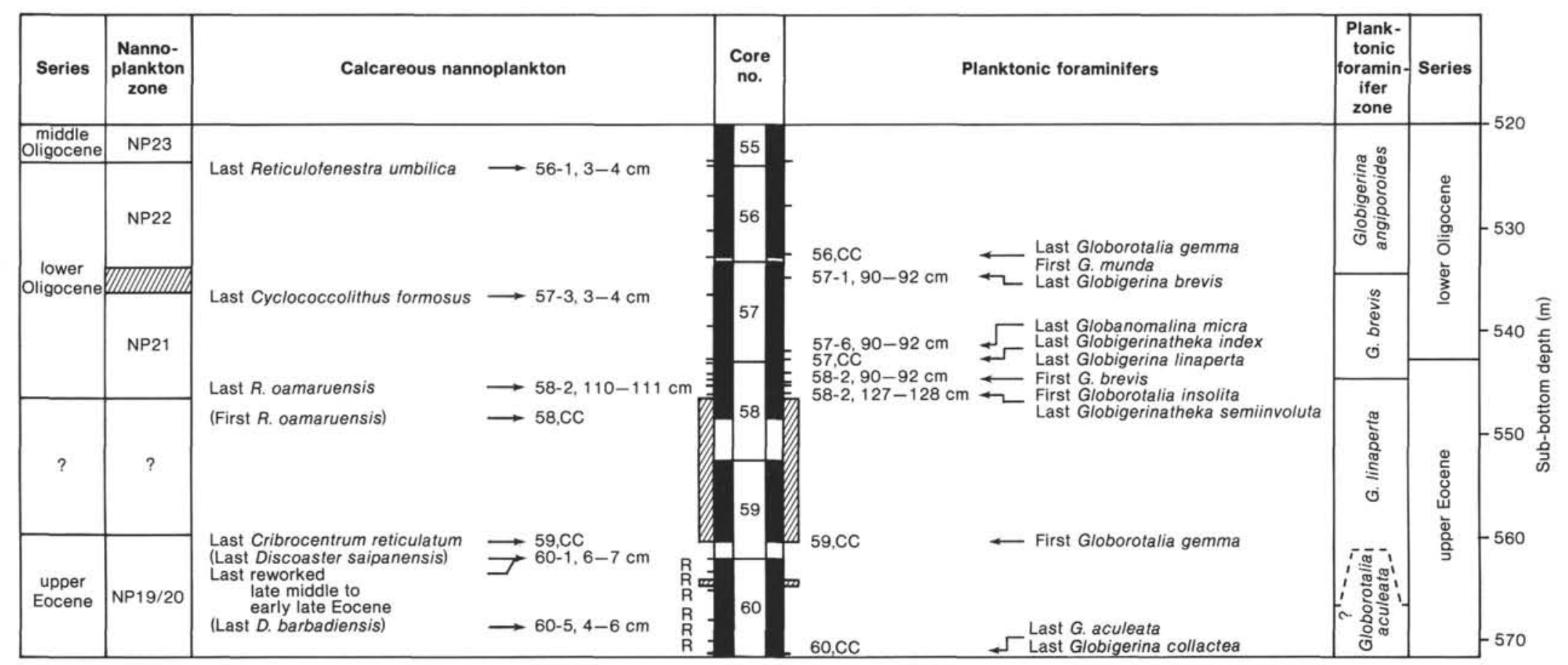

Figure 4. Last or first occurrences of important calcareous nannoplankton and planktonic foraminiferal species about the Eocene/Oligocene boundary in Hole 593, at $40^{\circ} 30.47^{\prime} \mathrm{S}$. Black $=$ recovered material, hachures $=$ volcanogenic material, $\mathrm{R}=$ reworked middle to early late Eocene calcareous nannoplankton, parentheses indicate that species are too rare and too poorly preserved to be sure of last occurrence. 


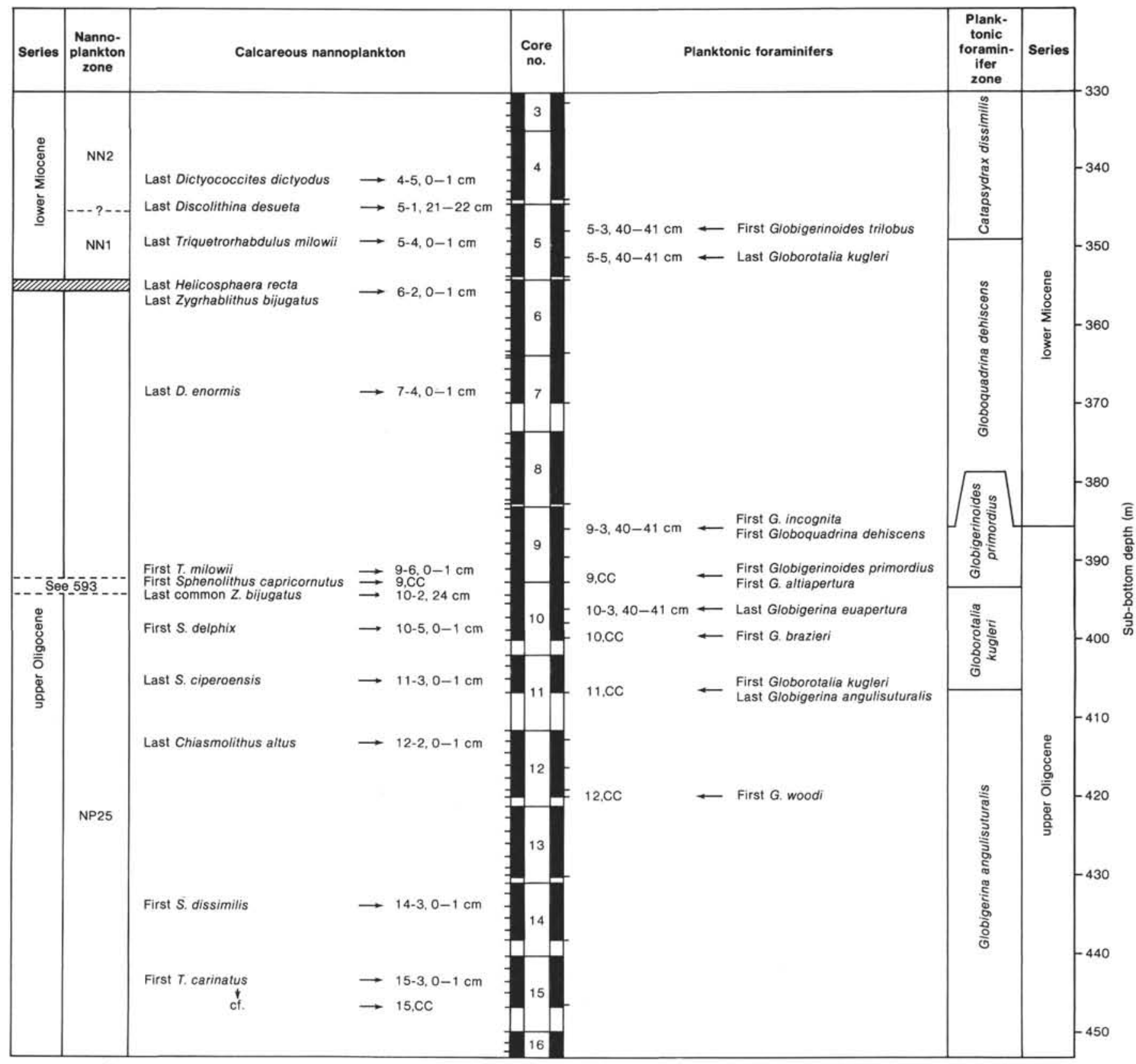

Figure 5. Last or first occurrences of important calcareous nannoplankton and planktonic foraminiferal species about the Oligocene/Miocene boundary in Hole $588 \mathrm{C}$ at $26^{\circ} 06.7^{\prime} \mathrm{S}$. Black $=$ recovered material.

above the last occurrence of $C$. tricorniculatus, although the latter is not a reliable marker in this high-latitude position.

\section{Pliocene/Pleistocene Boundary}

Until recently the first evolutionary appearance of Globorotalia truncatulinoides has been used to position the Pliocene/Pleistocene boundary at approximately $1.8 \mathrm{Ma}$, and this method was used during Leg 90 . At Sites 586 to 592 the boundary can be located with confidence, because G. tosaensis, the ancestor of the marker, is present; at Site 593 the ancestor is present in low numbers and at Site 594 it is absent, making placement of the boundary unreliable.
The Pliocene/Pleistocene boundary as identified by calcareous nannoplankton is commonly marked by the last occurrence of Discoaster brouweri in low and middle latitudes. This datum level is close to the first evolutionary appearance of Globorotalia truncatulinoides and near the base of the Olduvai Paleomagnetic Chron. In high latitudes, discoasters are rare or even missing and are not very reliable for identification of the Pliocene/ Pleistocene boundary. However, Cyclococcolithus macintyrei (which seems to have its last occurrence consistently above the last occurrence of $D$. brouweri near the top of the Olduvai Chron) was recently dated as 1.45 Ma by Backman and Shackleton (1983). This species may serve in high latitudes to approximate the Pliocene/ 


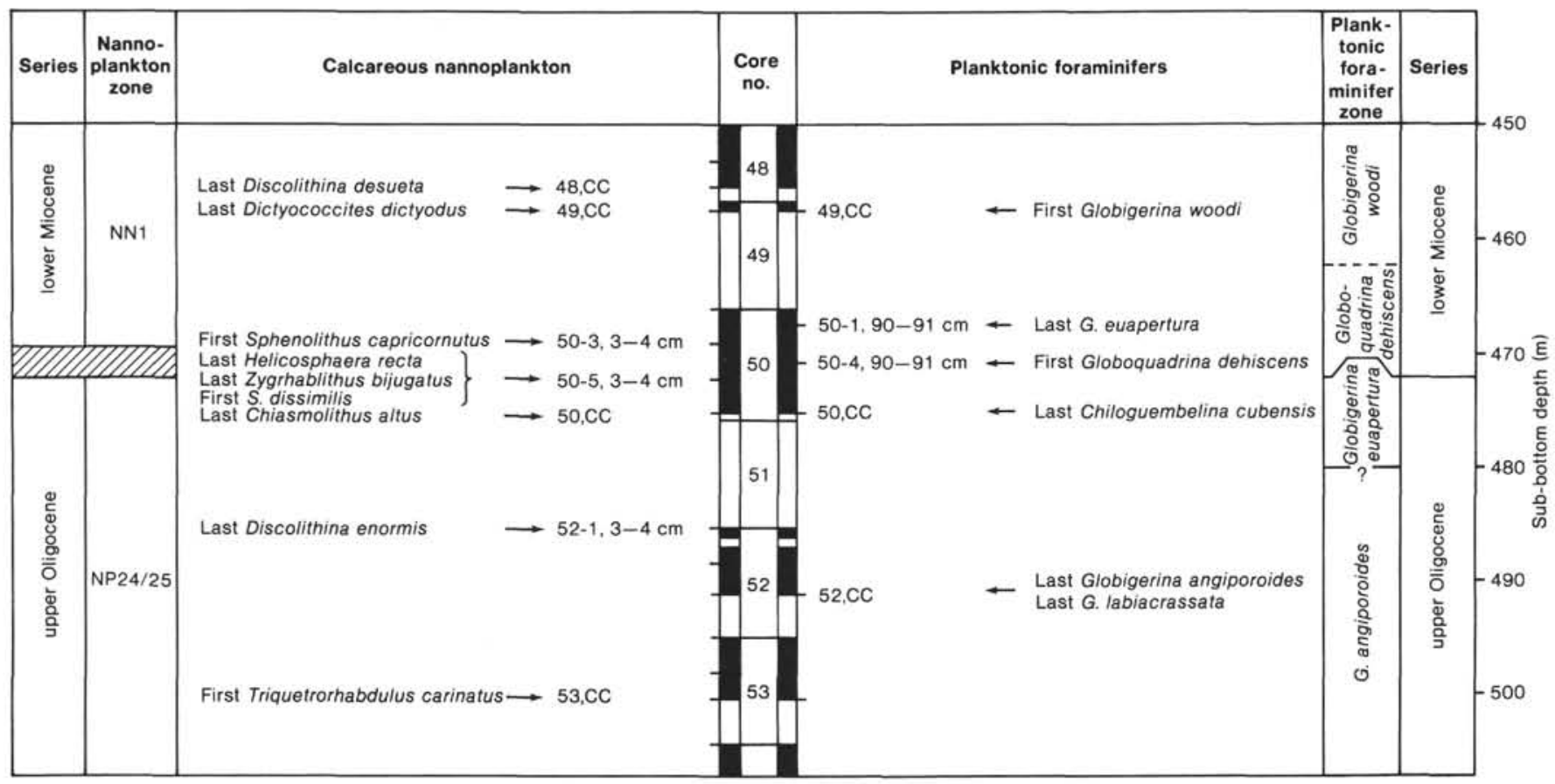

Figure 6. Last or first occurrences of important calcareous nannoplankton and planktonic foraminiferal species around the Oligocene/Miocene boundary in Hole 593, at $40^{\circ} 30.47^{\prime} \mathrm{S}$. Black = recovered material.

Pleistocene boundary, as it serves also to subdivide nannoplankton Zone NN19 into a short lower (NN19a) and longer-lasting upper (NN19b) interval. Figure 8 clearly demonstrates these difficulties in higher latitudes, where, between Sites 592 and 593, the D. brouweri datum crosses the $G$. truncatulinoides datum, which in turn crosses that of $C$. macintyrei between Sites 593 and 594 .

\section{Hiatuses}

The mechanisms that cause hiatuses are under scrutiny, but the subject is still under the influence of the idea of large changes in sea level proposed by Vail et al. (1977). On Leg 90 two unconformities were detected.

The first hiatus was noted at Site 588 in Core $588 \mathrm{C}$ 18 , about $470 \mathrm{~m}$ sub-bottom, separating sediments of the late Oligocene Chiloguembelina cubensis Zone (and Zone NP24) from the middle Eocene calcareous nannoplankton Zone NP15/NP16. The unconformity represents a time-gap of about 19 m.y. A similar unconformity was found at nearby Site 208 on Leg 21 (Fig. 1).

The second hiatus detected at Site 592 in Core 33 separates the Oligocene Globigerina angiporoides Zone (and NP22) sediments below from the lower Miocene Globigerina connecta Zone (and Zone NN2) above; this unconformity represents an interval of about 15 m.y.

The areal extent and the various interpretations regarding the cause or causes of the unconformity at about $30 \mathrm{Ma}$ in the southwest Pacific have been discussed by a number of workers (Carter and Landis, 1972; Kennett et al., 1974; Kennett, Houtz, et al. 1975; Edwards, 1975; Jenkins, 1975; Findlay, 1980; Loutit and Kennett, 1981; Carter and Landis, 1982; Lewis and Bellis, 1984). An unconformity in deep-sea deposits such as the one at Site 592 was probably caused by erosion and nondeposi- tion arising from active bottom waters, whereas in the shallower continental shelf deposits nondeposition was caused by a lowering of sea level.

The factors which caused the late Oligocene unconformity are probably related to events which were taking place on and around Antarctica at this time. The active bottom water and the lowering of the sea level were probably related to a combination of the development of the Circum-Antarctic Current at about 30 Ma (Jenkins, 1974, $1978 \mathrm{a}, \mathrm{b}$ ) and the development of initial continental ice sheets on Antarctica at about 29-30 Ma (Keigwin and Keller, 1984; Miller and Thomas, in press).

\section{ACKNOWLEDGMENTS}

Data summarized here include that obtained by our colleagues J. P. Caulet, Paul Ciesielski, William Lohman, and M. S. Srinivasan during shipboard studies or during and after the postcruise meeting at Scripps Institution of Oceanography. Martina Bundschuh helped to assemble the data for the drafts of Figures 3 to 8 . Thanks are also due to the Deutsche Forschungsgemeinschaft for supporting this study.

\section{REFERENCES}

Backman, J., and Shackleton, N. J., 1983. Quantitative biochronology of Pliocene and early Pleistocene calcareous nannoplankton from the Atlantic, Indian and Pacific Oceans. Mar. Micropaleontol., 8: 141-170.

Bombita, G., and Rusu, A., 1981. New data on the Eocene/Oligocene boundary in the Romanian Carpathians. Palaeogeogr., Palaeoclimatol. Palaeoecol., 36:213-222.

Bukry, D., 1973. Low-latitude coccolith biostratigraphic zonation. In Edgar, N. T., Saunders, J. B., et al., Init. Repts. DSDP, 15: Washington (U.S. Govt. Printing Office), 685-703.

Carter, R. M., and Landis, C. A., 1971. Correlative Oligocene unconformities in southern Australasia. Nature (Physical Sci.), 237:12-13. 1982. Appendix: Oligocene unconformities in the South Island. J. R. Soc. N. Z., 12:42-46.

Findlay, R. H., 1980. The Marshall Paraconformity (Note). N.Z. J. Geol. Geophys., 23:125-133. 
Finlay, H. J., 1939. New Zealand Foraminifera: key species in stratigraphy, No. 3. Trans. $R$. Soc. N. Z., 69(3):309-329.

Hornibrook, N. de B., 1958. New Zealand Upper Cretaceous and Tertiary foraminiferal zones and some overseas correlations. Micropaleontology, 4(1):25-38.

, 1984. Globorotalia (planktic foraminifera) at the Miocene/ Pliocene boundary in New Zealand. Palaeogeogr., Palaeocolimatol., Palaeoecol., 46:107-117.

Jenkins, D. G., 1963. The Eocene-Oligocene boundary in New Zealand. N. Z. J. Geol. Geophys., 6:107. 1966. Planktonic foraminiferal zones and new taxa from the Danian to lower Miocene of New Zealand. N. Z. J. Geol. Geophys., 8:1088-1125.

1971. Cenozoic Planktonic Foraminifera of New Zealand. N. Z. Geol. Surv. Paleontol. Bull., 42.

1974. Initiation of the proto-Circum-Antarctic Current. $\mathrm{Na}$ ture, 252(5482):371-373.

1975. Age and correlation of some unconformities in the New Zealand region. Geol. Soc. N. Z. Newsl., 39:45-47. 1978a. Guembelitria aff. stavensis Bandy, a paleoceanographic marker of the initiation of the Circum-Antarctic Current and the opening of Drake Passage. In Bolli, H. M., Ryan, W. B. F., Init. Repts. DSDP, Supply to Vols. $38,39,40$, and 41 : Washington (U.S. Govt. Printing Office), 687-693.

1978b. Guembelitria samwelli Jenkins, a new species from the Oligocene of the southern Hemisphere. J. Foraminiferal Res., 8(2):132-137.

1981. Planktonic foraminifera and the Palaeogene/Neogene boundary in the southwest Pacific. In Search of the Palaeogene/ Neogene Boundary Stratotype. Giorn. Geol., Ser. 2a, 44:205-210.

Keigwin, L. D., and Keller, G., 1984. Middle Oligocene climatic change from equatorial Pacific DSDP Site 77. Geology, 12:16-19.

Kennett, J. P., Houtz, R. E., Andrews, P. B., Edwards, A. R., Gostin, V. A., et al., 1974. Development of the Circum-Antarctic Current. Science, 186:144-147.

Kennett, J. P., Houtz, R. E., Andrews, P. B., Edwards, A. R., Gostin, V. A., et al., 1975. Cenozoic paleoceanography in the southwest Pacific Ocean, Antarctic glaciation, and the development of the Circum-Antarctic current. In Kennett, J. P., Houtz, R. E., et al., Init. Repts. DSDP, 29: Washington (U.S. Govt. Printing Office), 1155-1169.

Lewis, D. W., and Bellis, S. E., 1984. Mid-Tertiary unconformities in the Waitaki Subdivision, North Otago. J. R. Soc. N. Z., 14(3): 251-276.

Loutit, T. S., and Kennett, J. P., 1981. New Zealand and Australian Cenozoic sedimentary cycles and global sea-level changes. Am. Assoc. Pet. Geol. Bull., 65:1586-1601.

Martini, E., 1971. Standard Tertiary and Quaternary calcareous nannoplankton zonation. In Farinacci, A. (Ed.), Proc. II Planktonic
Conf., Roma 1970 (Vol. 2): Rome (Edizioni Tecnoscienza), pp. 739-785.

1979. Calcareous nannoplankton and silicoflagellate biostratigraphy at Reykjanes Ridge, northeastern North Atlantic (DSDP Leg 49, Sites 407 and 409). In Luyendyk, B. P., Cann, J. R., et al., Init. Repts. DSDP, 49: Washington (U.S. Govt. Printing Office), 533-549.

Miller, K. G., and Thomas, E., in press. Late Eocene to Oligocene benthic foraminiferal isotopic record, Site 574 equatorial Pacific. In Mayer, L., Theyer, F., et al., Init. Repts. DSDP, 85: Washington (U.S. Govt. Printing Office).

Müller, C., 1976. Tertiary and Quaternary calcareous nannoplankton in the Norweigian-Greenland Sea, DSDP, Leg 38. In Talwani, M., Udintsev, G., et al., Init. Repts. DSDP, 38: Washington (U.S. Govt. Printing Office), 823-841.

1978. Remarks on biostratigraphically useful nannofossils in the Paleogene of the northern hemisphere. Newsl. Stratigr., 7: 45-52.

Okada, H., 1980. Calcareous nannofossils from Deep Sea Drilling Project Sites 442 through 446, Philippine Sea. In Klein, G. deV., Kobayashi, K., et al., Init. Repts. DSDP, 58: Washington (U.S. Govt. Printing Office), 549-565.

Poore, R. A., and Matthews, R. K., 1983. Late Eocene-Oligocene oxygen- and carbon-isotope record from South Atlantic Ocean, Deep Sea Drilling Project Site 522. In Hsü, K. J., LaBrecque, J. L., et al., Init. Repts. DSDP, 73: Washington (U.S. Govt. Printing Office), 725-735.

Riedel, W. R., and Sanfilippo, A., 1971. Cenozoic radiolaria from the western tropical Pacific, Leg 7. In Winterer, E. L., Riedel, W. R., et al., Init. Repts. DSDP, 7, Pt 2: Washington (U.S. Govt. Printing Office), 1529-1672.

Snyder, S. W., Müller, C., and Miller, K. G., 1984. Eocene-Oligocene boundary: biostratigraphic recognition and gradual paleoceanographic change at DSDP Site 459. Geology, 12:112-115.

Srinivasan, M. S., and Kennett, J. P., 1983. The Oligocene-Miocene boundary in the South Pacific. Geol. Soc. Am. Bull., 94:798-812.

Steininger, F. F., 1982. The Palaeogene-Neogene (Oligocene-Miocene) boundary. In Odin, G. S. (Ed.), Numerical Dating in Stratigraphy: New York (John Wiley), pp. 652-658.

Vail, R. P., Mitchum, R. M., and Thompson, S., 1977. Seismic stratigraphy and global changes in sea level, Part 4: global cycles of relative changes in sea level. In Plyton, C. E. (Ed.), Seismic Stratigraphy. Am. Assoc. Pet. Geol. Mem., 26:83-97.

Date of Initial Receipt: 6 March 1985

Date of Acceptance: 21 May 1985 


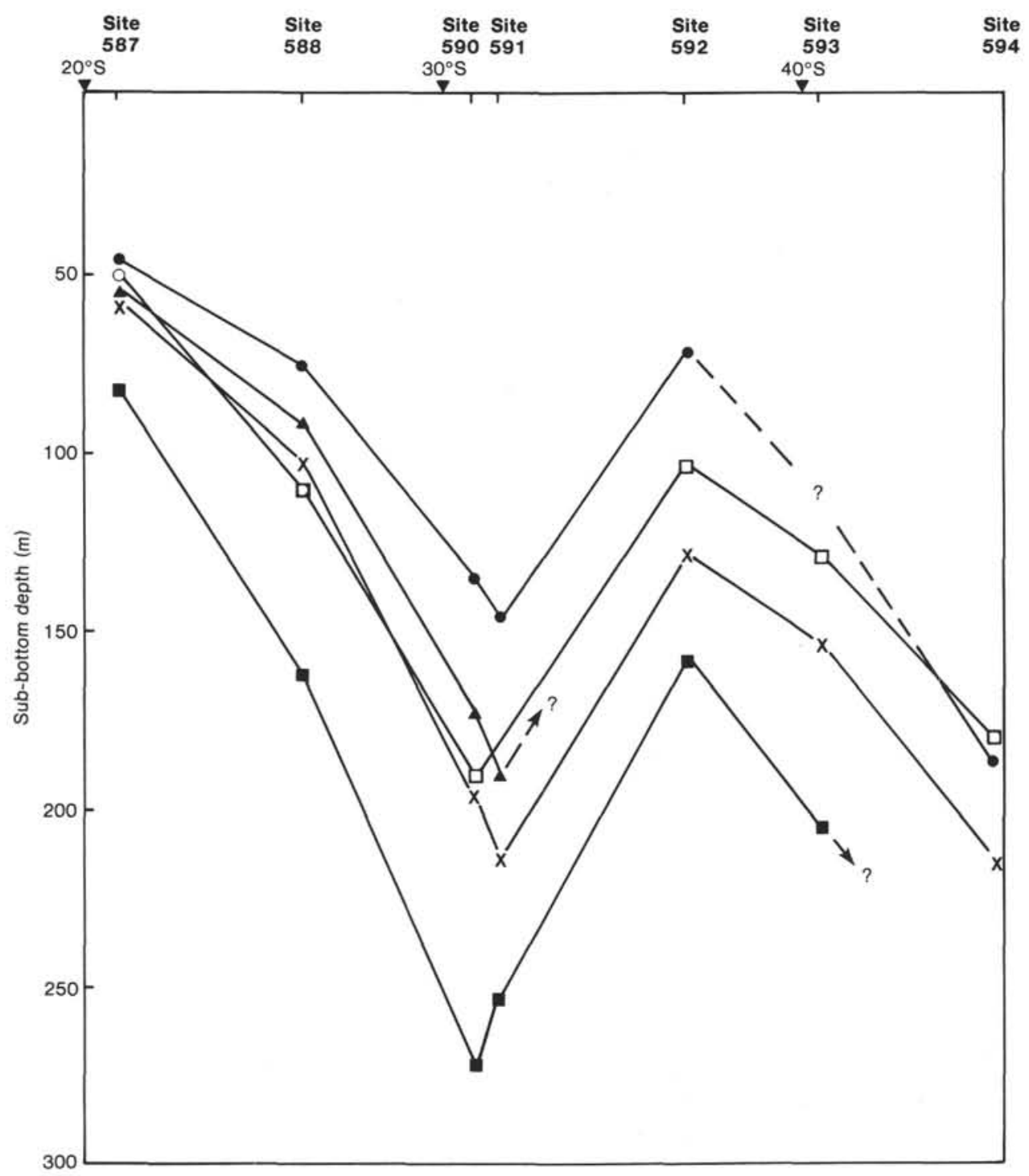

Figure 7. Occurrence of important calcareous nannoplankton and planktonic foraminiferal species about the Miocene/Pliocene boundary at Sites 587 through 594. = last occurrence of Ceratolithus tricorniculatus, $\mathbf{\Delta}$ = first occurrence of $C$. rugosus, $\mathrm{X}=$ last occurrence of Discoaster quinqueramus, $=$ first occurrence of $C$. primus, $\mathrm{O}=$ first occurrence of Globorotalia tumida,$\square=$ last occurrence of $G$. conomiozea. Diagram not corrected to sedimentation rates. 
E. MARTINI, D. G. JENKINS

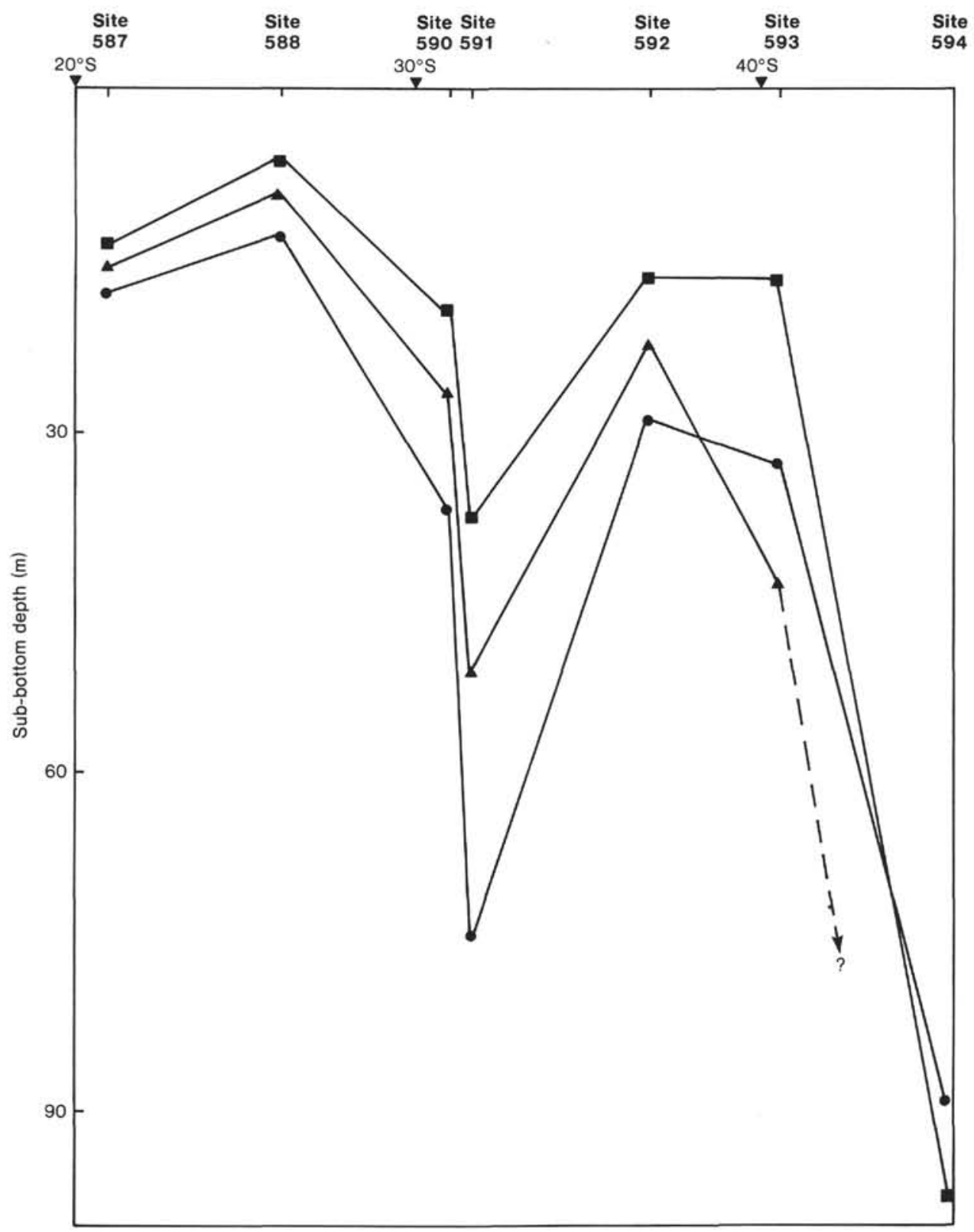

Figure 8. Occurrence of important calcareous nannoplankton and planktonic foraminiferal species about the Pliocene/Pleistocene boundary at Sites 587 through 594. macintyrei, $\mathbf{\Lambda}=$ last occurrence of Discoaster brouweri, $=$ first evolutionary appearance of Globorotalia truncatulinoides. Diagram not corrected to sedimentation rates. 